\title{
Impact of despotism on well-being through perceived stress and moderating role of emotional intelligence: $A$ testing of social exchange theory
}

\author{
Shazmina Saher ${ }^{1 *}$, Shahbaz Masih ${ }^{2}$, Valliappan Raju ${ }^{3}$ \\ 1, 2, 3 Limkokwing University of Creative Technology, Cyberjaya, Malaysia
}

Keywords
Perceived Stress (PS)
$\begin{aligned} & \text { Despotic leadership } \\ & \text { Emotional intelligence } \\ & \text { Well-being }\end{aligned}$
Received: $\quad 21 \quad$ September
$\begin{aligned} & \text { 2020 } \\ & \text { Accepted: } 2 \text { December } 2020 \\ & \text { Published: } 15 \text { February } 2021\end{aligned}$

Published: 15 February 2021

\begin{abstract}
As diversity and complexity are increasing in organizations, so there is increased demand for leaders who can face the challenges and maneuver the followers to accomplish organizational objectives. Dark leadership is becoming the emerging area of today's research, as it affects the personal life of employees, and has been ignored. This research study establishes the connection to measure the well-being of employees by predicting through Despotic Leadership (DL). Building the base on the Social Exchange Theory (SET), this study includes the PS as an intervening variable to explore how effects of DL travel from professional life to family lives of workers, which results in reduced well-being. The study examines the moderating effect of emotional intelligence on the relation between DL and PS. Two wave surveys of time lags were conducted to collect the data from 384 nurses of the hospital industry of Pakistan. SPSS 20 and AMOS 15 were applied for data analysis. The findings of the study show that DL significantly and negatively influences the well-being of employees through the intervention of PS. Emotionally intelligent individuals have better control over PS. This study contributes by giving a relational process model and can be implemented in hospitals to improve the well-being of nurses.
\end{abstract}

(C) 2021 The Author(s). Published by TAF Publishing.

\section{INTRODUCTION}

The negative relationship between employees as well as leaders is a perilous idea of debate in business \& management (Capezio, Wang, Restubog, Garcia, \& Lu, 2017). Researchers have concentrated on the dark or negative leadership (Naseer, Raja, Syed, Donia, \& Darr, 2016; Wu \& Hu, 2009) by unfolding the adverse effects of the destructive facet of leadership (Schyns \& Hansbrough, 2010) on employees' performance (Aryee, Chen, Sun, \& Debrah, 2007) like turnover, absenteeism, and efficiency (Tepper, Duffy, Henle, \& Lambert, 2006). Some other researchers highlighted the negative effects of DL in terms of PS (Harvey, Stoner, Hochwarter, \& Kacmar, 2007), and divergent work behavior (Duffy, Ganster, \& Pagon, 2002). Stress and job satisfaction are also consequences of dark leadership (Chen, Tang, \& Wang, 2009; Tepper, 2000; Tepper, Duffy, Hoobler, \& Ensley, 2004). The manners of destructive leadership are designated as abusive supervision (Tepper et al., 2004), trivial tyranny (Ashforth, 1994), and DL (Aronson, 2001). DL is the main indicator of the negative side of leadership but is under-researched in leadership and management area (Hewawitharana, Saher, Daniel, Masih, \& Daniel, 2020; Naseer et al., 2016).

As per A. H. De Hoogh and Den Hartog (2008) DL is a trend of leaders to behave in proponent as well as the authoritarian manner for the sake of self-interest, bragging, and to exploit their subordinates. In DL, leaders are highly egocentric that hunt for personal benefits at followers' expense (De Clercq, Fatima, \& Jahanzeb, 2019) and despotic leaders require unconditional obedience from their subordinates and exploit them by monitoring the system, for their personal benefits (Schilling, 2009). Hence, despotic leaders work against the legitimate interests of their organizations by committing themselves to moral corruption (Aronson, 2001). Un-

${ }^{*}$ corresponding author: Shazmina Saher

$\dagger$ email: shazminasaher79@gmail.com 
fair and unethical behavior of despotic leaders negatively impacts the followers' job performance in the organization, organizational citizenship behaviors, creativeness, as well as well-being (Bilal \& Zia-ur Rehman, 2017; Naseer et al., 2016). Although DL is increasingly damaging to workers, there is no research on its harmful effect on the well-being of employees.

DL behavior is not influencing the followers only but customers, organizations, families, and society as well. In despotism, leaders are not concerned with the followers' well-being (Thoroughgood, Sawyer, Padilla, \& Lunsford, 2018) which meaningfully damages the mental well-being of employees and reduces the ability for job performance (Chi, Tsai, \& Tseng, 2013; Schilling, 2009; Zhang \& Xie, 2017). The investigation has found that these habits are linked to numerous negative effects, including decreased job satisfaction, interpersonal engagement, mental fatigue and organization, sales intentions, family tension, and psychological distress among workers (Aasland, Skogstad, Notelaers, Nielsen, \& Einarsen, 2010; Ashforth, 1994; Greenhaus, 2003; Hershcovis et al., 2007; Schyns \& Schilling, 2013). Hence exploring the dark leadership is crucial for organizations (Hoobler \& Hu, 2013) and there is a need for further studies (Collins \& Jackson, 2015; Schyns \& Schilling, 2013) to look into the causes of DL and its negative impact on subordinates' well-being. This study focuses on the study gap by investigating the destructive impact of DL on assistants' well-being.

This research reflects on the significance of role definitions within these theoretical frameworks. For example, within SET, emotional intelligence concepts arise as a collection of abilities which lead to correct self-assessment of feelings as well as identification of emotional indentations in others as well as usage of emotions to inspire as well as succeed in life (Greiner \& Ennsfellner, 2010). Jordan, Ashkanasy, and Hartel (2002) recommended incorporating emotional intelligence in organizational behavior models. On the basis of the reciprocity concept given by Gouldner (1960) SET proposes that individuals provide benefits to others in hopes of obtaining benefits of equal value back from them (Blau, 1964; Barquet, 2019). In comparison with economic exchange relations in which incentives are offered and obtained by a single quota, social exchange relations are distinguished by a long-term free flow of transactions. Both the parties in the relationship contribute and gain benefits, with the type and timing of contributions left to the giver and not the receiver's discretion (Organ \& Bateman, 1983; Konovsky \& Pugh, 1994; Pillai, Schriesheim, \& Williams, 1999; Tepper, 2000). It is worth noting that, given the shared nature of social sharing relationships, the obligations to participate inherently follow expectations of gaining from them. Social exchange responsibilities give beliefs to each party about what the other party expects, help to frame or describe the roles for members of the relationship. People who want to maintain reciprocally advantageous social exchange relationships, carefully meet the expectations of partners and regard this conduct as a duty within the relationship regardless of its formal prescription. Consistent with this understanding, the findings show that employees facing DL governed by norms of social exchange face PS which affects their well-being (Alatrash, 2018; Tepper et al., 2006).

SET is a crucial model to understand behavior at the workplace (Homans, 1958) that emphasizes continuous connections which create responsibilities among the social network of employees at the workplace (Richard \& Emerson, 1976). The interdependent relationship can grow into a loyal, trusting, and mutual commitment, as indicated based on established interactive exchange rules. Concentrating on social exchange associations in workplaces classify different employees'- stakeholders' social exchange associations (like the direct manager, coworkers, suppliers, clients, and operational company) which impact behavior. SET along with the emphasis on social transactions and associations in the company, workplace features, the social communications among administration/managers as well as juniors, and the outcome of that association for employees and organization. The relevant hypothesized relations were in line with SET expectations as well as accomplish acknowledged literature gaps.

Therefore, the current study efforts to explore the level at which despotic leadership influences the well-being of employees. Thereupon, this research explores how despotic leadership creates PS. The emotional intelligence moderates association among despotic leadership and PS, as well as the dependent variables, has been explored too. Since in a high power distance culture, the dark side of leadership is further evident (Stajkovic \& Luthans, 1998) as juniors are anticipated to comply with the orders of their supervisors unconditionally in such type of culture, so employees working in Pakistani culture are most fit for this study (Naseer et al., 2016). The healthcare sector is one of the nation's main service sectors, as well as concerns such as the well-being of nurses, need academic consideration (Nadeem, Zia-uD din, Riaz, Shafique, \& Sattar, 2018). The research demonstrates which such adverse behaviors generally a consequence of managers' leadership style (Asrar-ul Haq \& Kuchinke, 2016; Daniel, Saher, \& Hewawitharana, 2020). Hence, current research is to examine part of despotic leadership to well- 
being in Pakistan's healthcare sector with moderated mediation model (Figure 1). The healthcare sector is the mainstay of any nation's well-being, especially emerging states (Mills, 2014).

\section{LITERATURE REVIEW AND HYPOTHESES DL and PS}

The stress that a man perceives is how much more than his capacity to cope with environmental requirements. PS is classified as "the result variable - measuring experienced stress levels concerning stressful events, processes of coping and personality factors, etc." (Cohen, Kamarck, \& Mermelstein, 1983; Tripathi \& Bharadwaja, 2020).

Leadership is a key factor in assessing levels of PS in workers and the strategies to cope with that (Gilbreath \& Benson, 2004; Ryska, 2002). Aggressive leadership has become increasingly evidence of negative consequences for assistants, containing depression and anxiety (Tepper, 2000) and burnout (Aryee et al., 2007; Harvey et al., 2007; Wu \& $\mathrm{Hu}, 2009)$. As despotic leaders are narcissistic, autocratic, exploitable, and unconsidered, they cause their dependents to undergo PS (Taşdelen-Karçkay \& Bakalım, 2017). Hence, we hypothesize:

H1: Employees' perception of despotic leadership is positively related to their PS.

\section{DL and Well-being (WB)}

Despotic leaders being authoritarian and unethical, have no ethical code of conduct, as well as they are not concerned with the needs of remains (Naseer et al., 2016). They may be dominant, controlling, vengeful, and exploitative in pursuing their interest (Aronson, 2001; Bass \& Stogdill, 1990; Howell \& Avolio, 1992). Negative implications of despotic leadership underscore the value of recognizing the impact of that generosity of leadership on exists of assistants. Considering the value of life satisfaction in assessing the wellbeing of the individual, a few pieces of research investigated the adverse impact of negative leaders on the satisfaction of life as well as indicated inadequate and unequal action through others in form of abusive supervision (Tepper, 2000) as well as workstation oppression (Dzuka \& Dalbert, 2007; Heller, Ezie, Otto, \& Timpano, 2018) is negatively linked to the well-being of followers. Following that line of debate, we claim that, in which the leader is coercive, exploitative, and vengeful, the emotional intelligence of subordinates to cope with like stresses is decreasing. As a consequence, subordinates experience perceived tension as well as are possible to have a small degree of well-being. Therefore, we assume that:
H2: Employees' perception of despotic leadership is positively and directly related to their well-being.

\section{PS as a Mediator}

Perceived stress is a psychological term that has been in focus over the last two eras. A stressor usually causes an anxiety response if the stressor is supposed as a risk or a request, or if surviving assets are seen as inadequate to cope with the situation (Cohen et al., 1983). Hewitt, Flett, and Mosher (1992) highlighted the significance of PS to fight against stress to forecast the signs related to stress. Whereas, in reality, stressors are experienced as negative psychological states and they are experienced as unmanageable and dangerous (Cohen et al., 1983; Pedrelli, Feldman, Vorono, Fava, \& Petersen, 2008). The association among despotic leadership as well as well-being can be mediated through the perception of stress (Lee, Joo, \& Choi, 2013). The perceived stress-related work has shown that Malaysian workers' quality of life has been greatly affected. Stress and control mechanisms considered may be essential goodness predictors (Ruiz-Aranda, Extremera, \& PinedaGalan, 2014). The psychological features of a person influence stress-related processing.

It is proved by the studies that personality influences wellbeing through stress-health behavior relations or perceived stress (Besser \& Shackelford, 2007) therefore, we presume that perceived stress is a mediator in the association among despotic leadership as well as well-being.

H3: Employees' perceived stress has a negative relation to their well-being.

H4: Employees' perception of despotic leadership has a negative relation to their well-being via perceived stress.

\section{Emotional Intelligence (EI) as a Moderator}

EI is a combination of skills that add to precise selfassessment of emotions, along with detection of emotions in others and effective utilization of emotions for motivation and achievement in the life of someone (Salovey \& Mayer, 1990). EI, however, may be an obliging individual resource to handle the emotional situations-playing a helpful part in the performance of emotional work (Van Dusseldorp, van Meijel, \& Derksen, 2011). The EI and health relationships are well-validated empirically by the two metaanalyses recently, based on 149 effect sizes as well as 27,713 applicants (Martins, Ramalho, \& Morin, 2010; Schutte, Malouff, Thorsteinsson, Bhullar, \& Rooke, 2007). According to Martins et al. (2010) adequacy and stability have already entered this line of study and emotional intelligence as a plausible health forecaster. The management of the emo- 
tions of others has been identified by Schutte et al. (1998). In a group of university scholars, he played a moderating role in the association between stress as well as suicidal attention. Significantly, enhancing individual stress resistance can be mainly supportive in the fight against burnout in nurses if the indication of moderating impact of emotional intelligence in that association is originated (Ciarrochi, Deane, \& Anderson, 2002).

EI has been related to the capability to offer a positive response as well as stimulate group accomplishment (Goleman, 195). In a research of 108 supervisors Baron (1990) discovers which incompetent criticism or incapability of subordinates to deliver a balanced view of their performance was the main reason for conflict in the workplace. Given that one-third of our population is made up of persons whose talents are so extremely specified which they may be effective solitary if their actions are well organized (Drucker, 1994). The development of essential social skills of emotional intelligence is required for achievement. Kelley and Caplan (1993) originated which greater performance was accomplished through researchers who completed an effort to form a network of professionals along with varied abilities which may be termed upon when required. Positive ties between individuals increase work satisfaction as well as reduce stress. Social relations networks enhance reliability as well as the obligation of employees to both working groups and managers. As commitments to the workgroup as well as a manager are crucial for organizational responsibility, individuals who are emotionally intelligent may have more commitments towards the organization.

The effect of emotional intelligence can be influenced in two ways by job control. To the degree that emotionally intelligent people portray themselves so that they deliver meaningful experiences Goffman (1959) they must have the freedom to choose the impressions of others from a variety of abilities to influence and direct their impressions. Emotional intelligence would also affect employee well-being through despotic leadership. Emotionally smart people can connect issues with the experience of their internal emotions. The comprehension of issues makes it further important because they apply it to different situations. This importance leads to more versatility as well as creativity in the approach that presupposes preference to decide and to pursue creative solutions. My secondary goal in this research is to examine moderating impact of emotional intelligence on the association among despotic leadership as well as their perceived stress performance.

H5: Emotional intelligence of employees has the moderating effect between their perception of despotic leadership and perceived stress.

\section{Research Model Proposed for Study}

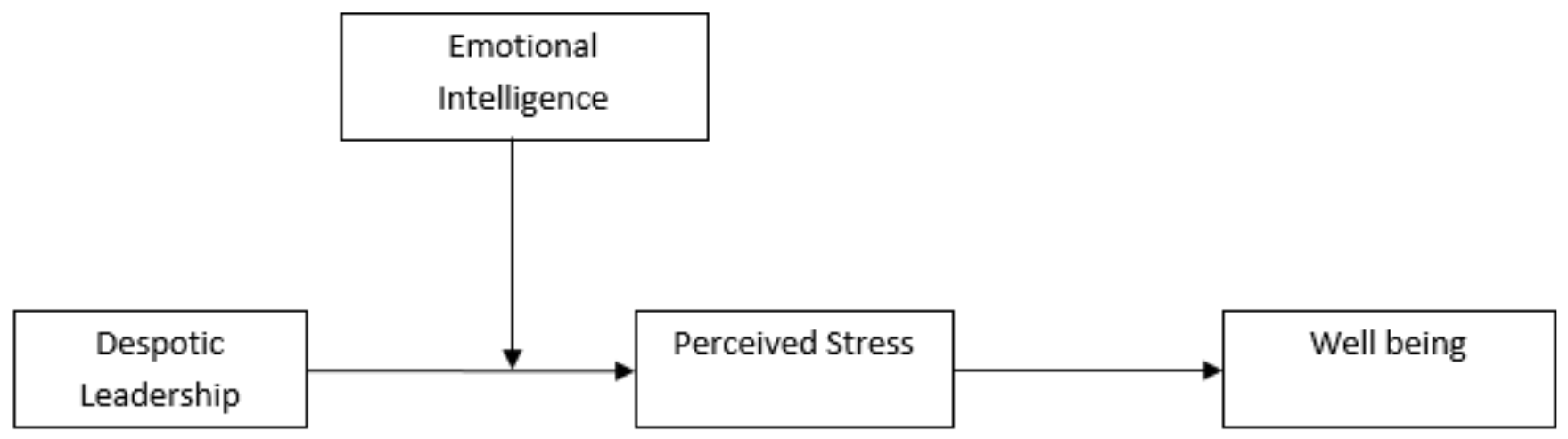

FIGURE 1. The following model depicts the hypothesized relationships of our study

\section{METHODOLOGY}

\section{Sampling Technique and Procedure for Data Collection}

Two wave survey was conducted to collect data to control the issue of common method variance (Podsakoff, MacKenzie, Lee, \& Podsakoff, 2003). Nurses were chosen as the respondents who used to work in public and private hospitals of Pakistan. The hospitals were approached to classify re- spondents through personal connections, as well as surveys were dispersed through researchers to individual respondents who volunteered themselves to take part in the survey. Participants signed approval procedures which clarified the intent of research as well as guaranteed full secretly. This was conveyed that whole answers will be available only to scholars that no data at the personal level will be pre- 
pared public as well as that only cumulative info will be exchanged.

Such protections assisted us in coping with social importance and gave to participants a sense of security. To enhance the return rate, respondents who were late and who did not respond were approached to complete the data collection process.

The data collection was accomplished through 2 on-site surveys, one of that assessed despotic leadership as well as emotional intelligence, and the other measured perceived stress as well as employee well-being. After the surveys were completed, the respondents located them in closed envelopes as well as returned them to interaction individuals. Scholars gathered answers from contact individuals. No economic compensation or additional benefits were given to respondents, as well as respondents were voluntary firstly, forms were dispersed to 500 nurses in important districts in all provinces, and 457 completed surveys were refunded. Surveys were performed within three to four weeks. After finalizing the complete questionnaires which matched two-time results, the final sample size was 384 to satisfy Krejcie and Morgan (1970) requirement, which is a 77 percent response rate after completing two surveys. Survey questions were designed in English, as universities as well as furthermost organizations in Pakistan usage English. The respondents were both men and women, both of whom were trained nurses and had strong language skills.

\section{Measures}

The current research followed all existing literature interventions evaluated in various countries, cultures, and work settings. The possibility of instrumentation errors is reduced by using the standardized scales developed to measure research variables (Luthans, Youssef, \& Avolio, 2007).

\section{DL}

A six-item scale was used to measure despotic leadership, which was established by A. H. B. De Hoogh and Den Hartog (2008). The example items involved "My supervisor is punitive and has no pity or compassion," and "My supervisor gives orders." Respondents rated on a 5-point Likert scale, where 1 = strongly disagree and $5=$ strongly agree. The Cronbach's alpha for this scale is 0.79 , which shows the reliability for further analysis.

\section{EI}

This study measured employees' emotional intelligence by using Wong as well as Law EI Scale (WLEIS) (Wong \& Law, 2002). This scale having sixteen evaluated four elements of emotional intelligence that Salovey and Mayer (1990) conceptualized: self-emotion appraisal, other-emotion appraisal, use of emotion, as well as regulation of emotion. The sample items include "I have a good sense of why I have certain feelings most of the time" (self-emotion appraisal), "I am a good observer of others' emotions" (other-emotion appraisal), "I am able to control my temper and handle difficulties rationally" (regulation of emotion), as well as "I always set goals for myself and then try my best to achieve them" (use of emotion). The Cronbach's alpha of this variable is 0.77 .

\section{PS}

A perceived stress scale of Cohen et al. (1983) is being used to assess how unpredictable, uncontrollable, and debilitating respondents' pressure is (e.g., how much have you thought you were incapable to control the significant belongings to your life in last month?).

In this analysis, a validated Korean short version of the PS scale K-PSS was utilized (Park \& Seo, 2010). The K-PSS is a ten-item self-report survey with a five-point Likert scale ranging from 0 (never) to 4 (always) (very often). The total score ranges from 0 to 40 , with extreme scores signifying a greater level of PS.

The K-two-factor PSS's framework seemed to better match data as well as was strongly linked to depression and anxiety measures, suggesting that it is a reliable indicator for the Korean population. The current study found the Cronbach's alpha 0.80 .

\section{WB}

Job-related well-being was measured by the scale having six items dependent on the WHO-five well-being scale (Brahler, Muhlan, Albani, \& Schmidt, 2007), which was rated on a 5 point-Likert-Scale, 1 (not at all) to 5 (completely). A sample item of this scale is "Do you like being at work?" The Cronbach's alpha for this variable is 0.80 .

\section{RESULTS}

SEM - Structural Equation Modeling 16 was used to analyze data and check the hypothesis. The normality, skewness, kurtosis, and all related tests were run in SPSS 20. Hypotheses were tested by SEM - Structural Equation Modeling through AMOS 15. The first step was to perform the confirmatory factor analysis to build the estimation model that categorized the observed variables as far as "verifiable" latent variable, for example, independent or dependent, and an estimation error term. All latent variables were connected to all other latent variables. Subsequently, we tweaked the estimation model to imply the guess hypothetical system. The methodology we used in a study provides 
a scientific strategy to observe the fitness of the estimation model as well as the derivation for anticipated postulates. So, as the check intervention hypotheses, had bootstrap strategy utilized certainty interim technique? This study used bootstrapping for confirmation of the intervention impact due to its precision to find out certainty interims for the mediation impact when there is a mediation impact non-zero.

\section{Validate Analysis}

CFA was conducted to validate the distinctiveness of all the constructs in this research. The data in Table 1 depicts the model fitness (IFI $=.95$, TLI $=.97$, CFI, .93, RMSEA $=.04$ ). The Confirmatory Factor Analysis outcomes confirmed satisfactory discriminant validity as well as also presented an absence of common method bias. Table 2 depicts correlations, descriptive statistics.

TABLE 1. Measurement model

\begin{tabular}{lllll}
\hline \hline Model & RMSEA & IFI & TLI & CFI \\
\hline Original model & .21 & .85 & .69 & .81 \\
Revised & .04 & .95 & .97 & .93 \\
\hline \hline
\end{tabular}

TABLE 2. Correlations

\begin{tabular}{lllllll}
\hline \hline Variables & Mean & SD & $\mathbf{1}$ & $\mathbf{2}$ & $\mathbf{3}$ & $\mathbf{4}$ \\
\hline 1. Despotic Leadership & 2.6 & .43 & $(0.79)$ & & & \\
2. Perceived Stress & 2.9 & .39 & $.65^{* *}$ & $(0.80)$ & & \\
3. Emotional Intelligence & 3.3 & .45 & .53 & $-.44^{*}$ & $(0.77)$ & $(0.80)$ \\
4. Well being K & 3.1 & .37 & $.45^{* *}$ & $-.53^{* *}$ & $.51^{* *}$ & $(0.6$ \\
\hline \hline
\end{tabular}

**Correlation is significant at the 0.01 level (2-tailed).

* Correlation is significant at the 0.05 level (2-ailed).

Total sample size, $n=384$

Structure Equation Modeling (SEM) using AMOS 16 was engaged to analyze the hypotheses and we followed the two-step approach for analysis which is the recommendation of Anderson and Gerbing (1988). Each latent variable was connected with all other latent variables. certainty interim technique of bootstrapping was used to test the hypotheses. We used bootstrapping to verify the intervention impact due to its accuracy in finding out the certainty interims to check the impact of mediation when there is a mediation impact non-zero.

Table 3 depicts the examination; the unconstrained multiple-factor model shows the superior to the particular factor model did. The outcomes of $\mathrm{H} 1$ are shown by the direct path model, that forecasts which DL is emphatically identified with PS. The direct relationship provides the con- sequences for $\mathrm{H} 1$, which predicts $\mathrm{DL}$ is positively related to PS as well as results support this relationship $(b=.48, p<$ 0.001 ) respectively. $\mathrm{H} 2$ which is forecast $\mathrm{DL}$ is positively related to WB and results supports this relationship $(b=.44, p$ $<0.001)$. H3 this hypothesis has been forecasted PS is negatively related to $\mathrm{WB}$ and results shows that relationship $(b$ $=.51, p<0.005)$. H4 this hypothesis has been forecasted indirect relationship DL is negatively related to WB via PS with the help of results $\mathrm{DL} \rightarrow \mathrm{PS} \rightarrow \mathrm{WB}$ (indirect effect $=0.15$, CI 95\%, [0.04], $p \leq 0.001$ ) shown in Table 4. In hypothesis 5, we hypothesize EI as a moderator among the relationship of DL and PS. Outcomes support the variable of the study. According to the slope test, adjustment of beta is a similar way as proposed, at_1 standard deviation of moderator's mean worth which has been shown in Table 5 .

TABLE 3. [Hypothesized model] standardized direct path coefficients

\begin{tabular}{llll}
\hline \hline & Path & Estimate & SE \\
\hline H1 & DL $\rightarrow$ PS & $0.48^{* * *}$ & 0.07 \\
H1 (b) & DL $\rightarrow$ WB & $0.44^{* * *}$ & 0.06 \\
H1 (c) & $\rightarrow$ BN & $0.51^{* * *}$ & 0.04 \\
\hline \hline
\end{tabular}

TABLE 4. Indirect effects with bootstrap outcomes

\begin{tabular}{llllll}
\hline \hline & Paths & Effect & SE & LL 99\% CI & UL99\%CI \\
\hline $\mathrm{H} 2 \mathrm{a}$ & Psy $\rightarrow \mathrm{OC} \rightarrow \mathrm{BN}$ & 0.15 & 0.04 & 0.02 & 0.33 \\
\hline \hline
\end{tabular}


TABLE 5. Moderation analysis result

\begin{tabular}{lllllllll}
\hline \hline & B & SE & LLCI & ULCI & B & SE & LLCI & ULCI \\
\hline Constant & 5.72 & .56 & 4.49 & 5.80 & 2.51 & .34 & 1.96 & 3.35 \\
EI & $-.114^{*}$ & .08 & -.37 & -.06 & $.125^{*}$ & .04 & .02 & .26 \\
DL & $-.176^{* *}$ & .09 & -.33 & -.02 & $.31^{* * *}$ & .06 & .22 & .45 \\
EIxDL & $-.228^{* * *} .07$ & -.32 & -.07 & $.08^{*}$ & .05 & .03 & .17 \\
$1 R^{2}$ due to Interaction & $.039^{* * *}$ & & & & $.013^{*}$ & & & \\
\hline \hline
\end{tabular}

\section{DISCUSSION \& CONCLUSION}

By combining DL, PS, EI, and WB with SET, this study found that DL influences the well-being of nurses through PS. The findings of this research discovered that despotic leaders directly influence the well-being of employees, whereas perceived stress works as a partial mediator between the relationship of DL and WB by mediating partially. Our study depicts that despotism badly affects the organizational environment by being the reason for perceived stress among employees which consequences in lower well-being. We found in a previous study which was conducted by Kant, Skogstad, Torsheim, and Einarsen (2013) that dark leadership creates an unhealthy environment for employees at work and personal, which is the reason for negative behaviors and poor quality of life. Our study makes a significant contribution in the area of dark leadership by revealing that despotic leadership negatively affects the well-being of employees. Our study makes the addition in the existing literature on the apprehensive side of leadership, well-being, and SET. In addition to that, the results of our study are coherent with the results of despotic leadership adversely affects the well-being of employees.

This research study contributed by expanding the dark leadership area and its negative effects on the well-being of employees. We combined together with the despotism of leadership and the well-being of employees in hospitals of Pakistan to find out the connections between despotism and employee's well-being in nurses, which is regarded high position in the community (Hofstede, 1983). Our study explored the negative effects of DL on the work as well as the personal lives of employees. We also explored that how despotic leadership influences well-being through perceived stress.

\section{Practical Implications}

As our study found that despotic leadership adversely affects the well-being of nurses who work in different hospitals, so the management of hospitals can identify the despotism in leaders to take care of the well-being of nurses. A hospital that ignores the despotism in leadership who wants to control to gain power, is at threat of gain of per- ceived stress among nurses which will ultimately affect their well-being. Nurses with decreased quality of life are unable to perform well which causes dissatisfaction for patients. The best for hospitals is to figure out the despotism while selecting the leaders and take necessary measures to decrease the perceived stress by increasing emotional intelligence and workers should have access to the HR department, to obtain input regarding despotism. Our study can be helpful practically if the human resource department of the hospital put constraints on despotic leaders through the cultivation of a positive atmosphere and help out the suffering employees.

\section{Limitations of Study and Recommendations}

The first limitation of this study is that respondents participated, most of them were female, and all the data was collected from the hospital industry of Pakistan. Future researchers should target the sample demonstrating male orientation as well and data collection should be expanded to some other industries as well. The second limitation of our study is that the collection of data were done through the self-reporting method. According to Podsakoff et al. (2003) the self-reporting method of data collection can be subjected to biases. Yet, we used various ways to avoid the common method variance. Third, current research studies only one outcome variable that is well-being. Future researchers are recommended to take the impact of other variables like employee innovation, turnover intention, and counterproductive work behavior.

Although this study has many limitations, still it is worthwhile to be implemented practically. This study will help to improve the well-being of nurses in hospitals in Pakistan through exchange relationships. Further, this study is useful for the management to implement the HR system to control despotism for the well-being of employees. Additionally, this study has addressed the concerns mentioned by Ferlie, Hartley, and Martin (2003) to use the quantitative data for analysis and theoretical research questions in the study of management sciences. 


\section{REFERENCES}

Aasland, M. S., Skogstad, A., Notelaers, G., Nielsen, M. B., \& Einarsen, S. (2010). The prevalence of destructive leadership behaviour. British Journal of Management, 21(2), 438-452. doi:https://doi.org/10.1111/j.1467-8551.2009.00672.x

Alatrash, A. (2018). Impact of using total quality management on the financial performance of companies listed on the Palestine exchange. International Journal of Business and Economic Affairs, 3(6), 244-252. doi:https://doi.org/10 .24088/IJBEA-2018-36001

Anderson, J. C., \& Gerbing, D. W. (1988). Structural equation modeling in practice: A review and recommended two-step approach. Psychological Bulletin, 103(3), 411-423.

Aronson, E. (2001). Integrating leadership styles and ethical perspectives. Canadian Journal of Administrative Sciences, 18(4), 244-256. doi:https://doi.org/10.1111/j.1936-4490.2001.tb00260.x

Aryee, S., Chen, Z. X., Sun, L.-Y., \& Debrah, Y. A. (2007). Antecedents and outcomes of abusive supervision: Test of a trickledown model. Journal of Applied Psychology, 92(1), 191. doi:https://doi.org/10.1037/0021-9010.92.1.191

Ashforth, B. (1994). Petty tyranny in organizations. Human Relations, 47(7), 755-778. doi:https://doi.org/10.1177/ 001872679404700701

Asrar-ul Haq, M., \& Kuchinke, K. P. (2016). Impact of leadership styles on employees' attitude towards their leader and performance: Empirical evidence from Pakistani banks. Future Business Journal, 2(1), 54-64. doi:https://doi.org/ 10.1016/j.fbj.2016.05.002

Baron, R. A. (1990). Countering the effects of destructive criticism: The relative efficacy of four interventions. Journal of Applied Psychology, 75(3), 235-245. doi:https://psycnet.apa.org/record/1990-27044-001

Barquet, E. A. G. (2019). Analysis of the consumer behavior of the members of the savings and credit cooperatives for the integration of electronic financial services in the city of Guayaquil . International Journal of Business and Administrative Studies, 5(5), 303-311. doi:https://dx.doi.org/10.20469/ijbas.5.10005-5

Bass, B. M., \& Stogdill, R. M. (1990). Bass \& stogdill's handbook of leadership: Theory, research, and managerial applications. California, CA: Simon and Schuster.

Besser, A., \& Shackelford, T. K. (2007). Mediation of the effects of the big five personality dimensions on negative mood and confirmed affective expectations by perceived situational stress: A quasi-field study of vacationers. Personality and Individual Differences, 42(7), 1333-1346. doi:https://doi.org/10.1016/j.paid.2006.10.011

Bilal, S., \& Zia-ur Rehman, M. (2017). The role of employee's mindfulness and human resource development climate towards public leadership behavior-analyzing the moderating impact of emotional capital. Journal of Administrative and Business Studies, 3(5), 248-254. doi:https://doi.org/10.20474/jabs-3.5.4

Blau, P. M. (1964). Exchange and power in social life. New Jersy, NJ: Transaction Publishers.

Brahler, E., Muhlan, H., Albani, C., \& Schmidt, S. (2007). Teststatistische prüfung und normierung der deutschen versionen des EUROHIS-QOL Lebensqualität-index und des WHO-5 Wohlbefindens-index. Diagnostica, 53(2), 83-96. doi:https://doi.org/10.1026/0012-1924.53.2.83

Capezio, A., Wang, L., Restubog, S. L., Garcia, P. R., \& Lu, V. N. (2017). To flatter or to assert? gendered reactions to machiavellian leaders. Journal of Business Ethics, 141(1), 1-11. doi:https://doi.org/10.1007/s10551-015-2723-0

Chen, C.-H. V., Tang, Y.-Y., \& Wang, S.-J. (2009). Interdependence and organizational citizenship behavior: Exploring the mediating effect of group cohesion in multilevel analysis. The Journal of Psychology, 143(6), 625-640. doi:https:// doi.org/10.1080/00223980903218273

Chi, N.-W., Tsai, W.-C., \& Tseng, S.-M. (2013). Customer negative events and employee service sabotage: The roles of employee hostility, personality and group affective tone. Work \& Stress, 27(3), 298-319. doi:https://doi.org/10.1080/02678373 .2013.819046

Ciarrochi, J., Deane, F. P., \& Anderson, S. (2002). Emotional intelligence moderates the relationship between stress and mental health. Journal of Clinical Nursing, 32(2), 197-209. doi:https://doi.org/10.1111/j.1365-2702.2012.04171.x

Cohen, S., Kamarck, T., \& Mermelstein, R. (1983). A global measure of perceived stress. Journal of Health and Social Behavior, 385-396. doi:https://doi.org/10.2307/2136404

Collins, M. D., \& Jackson, C. J. (2015). A process model of self-regulation and leadership: How attentional resource capacity and negative emotions influence constructive and destructive leadership. The Leadership Quarterly, 26(3), 386-401. doi:https://doi.org/10.1016/j.leaqua.2015.02.005 
Daniel, I., Daniel, Saher, S., \& Hewawitharana, A. (2020). Affiliative and self-enhancing humor in leadership and their relationship to employee well-being and creativity via LMX. Global Journal of Emerging Sciences, 2(1), 35-55. doi:https:// doi.org/10.37187/gjoes.0320.0201.05

De Clercq, D., Fatima, T., \& Jahanzeb, S. (2019). Ingratiating with despotic leaders to gain status: the role of power distance orientation and self-enhancement motive. Journal of Business Ethics, 6(8), 1-18. doi:https://doi.org/10.1007/s10551 -019-04368-5

De Hoogh, A. H., \& Den Hartog, D. N. (2008). Ethical and despotic leadership, relationships with leader's social responsibility, top management team effectiveness and subordinates' optimism: A multi-method study. The Leadership Quarterly, 19(3), 297-311. doi:https://doi.org/10.1016/j.leaqua.2008.03.002

De Hoogh, A. H. B., \& Den Hartog, D. N. (2008). Ethical and despotic leadership, relationships with leader's social responsibility, top management team effectiveness and subordinates' optimism: A multi-method study. Leadership Quarterly, 19(3), 297-311. doi:https://doi.org/10.1016/j.leaqua.2008.03.002

Drucker, P. (1994). The age of social transformation. Retrieved from https://bit.ly/3ieUacm

Duffy, M. K., Ganster, D. C., \& Pagon, M. (2002). Social undermining in the workplace. Academy of Management Journal, 45(2), 331-351. doi:https://doi.org/10.2307/3069350

Dzuka, J., \& Dalbert, C. (2007). Student violence against teachers: Teachers' well-being and the belief in a just world. European Psychologist, 12(4), 253-260. doi:https://doi.org/10.1027/1016-9040.12.4.253

Ferlie, E., Hartley, J., \& Martin, S. (2003). Changing public service organizations: Current perspectives and future prospects. British Journal of Management, 14(5), 35-50. doi:https://doi.org/10.1111/j.1467-8551.2003.00389.x

Gilbreath, B., \& Benson, P. G. (2004). The contribution of supervisor behaviour to employee psychological well-being. Work \& Stress, 18(3), 255-266. doi:https://doi.org/10.1080/02678370412331317499

Goffman, E. (1959). The moral career of the mental patient. Psychiatry, 22(2), 123-142.

Goleman, E. (195). Emotional intelligence: Why it can matter more than IQ. New York, NY: Bantam Books.

Gouldner, A. W. (1960). The norm of reciprocity: A preliminary statement. American Sociological Review, 4(7), 161-178. doi:https://doi.org/10.2307/2092623

Greenhaus, C. (2003). The relation between work family balance and quality of life. Journal of Vocational Behavior, 63(3), 510-531. doi:https://doi.org/10.1016/S0001-8791(02)00042-8

Greiner, L., \& Ennsfellner, I. (2010). Management consultants as professionals, or are they? Organizational Dynamics, 39(1), 72-77. doi:https://doi.org/10.2190/DUGG-P24E-52WK-6CDG

Harvey, P., Stoner, J., Hochwarter, W., \& Kacmar, C. (2007). Coping with abusive supervision: The neutralizing effects of ingratiation and positive affect on negative employee outcomes. The Leadership Quarterly, 18(3), 264-280. doi:https:// doi.org/10.1016/j.leaqua.2007.03.008

Heller, A. S., Ezie, C. C., Otto, A. R., \& Timpano, K. R. (2018). Model-based learning and individual differences in depression: The moderating role of stress. Behaviour Research and Therapy, 111, 19-26. doi:https://doi.org/10.1016/j.brat.2018 .09 .007

Hershcovis, M. S., Turner, N., Barling, J., Arnold, K. A., Dupré, K. E., Inness, M., ... Sivanathan, N. (2007). Predicting workplace aggression: A meta-analysis. Journal of Applied Psychology, 92(1), 228-235. doi:https://doi.org/10.1080/02678373 .2012 .660770

Hewawitharana, A., Saher, S., Daniel, K., Masih, S., \& Daniel, I. (2020). Influence of despotic leadership on personnel lives via emotional exhaustion and moderating role of perceived supervisory support: A testing of COR model. Global Journal of Emerging Sciencess, 2(1), 56-69. doi:https://doi.org/10.37187/gjoes.0320.0201.06

Hewitt, P. L., Flett, G. L., \& Mosher, S. W. (1992). The perceived stress scale: Factor structure and relation to depression symptoms in a psychiatric sample. Journal of Psychopathology and Behavioral Assessment, 14(3), 247-257. doi:https:// doi.org/10.1007/BF00962631

Hofstede, G. (1983). The cultural relativity of organizational practices and theories. Journal of International Business Studies, 14(2), 75-89. doi:https://doi.org/10.1057/palgrave.jibs.8490867

Homans, G. C. (1958). Social behavior as exchange. American Journal of Sociology, 63(6), 597-606. doi:https://doi.org/ $10.1177 / 0149206305279602$ 
Hoobler, J. M., \& Hu, J. (2013). A model of injustice, abusive supervision, and negative affect. The Leadership Quarterly, 24(1), 256-269. doi:https://doi.org/10.1016/j.leaqua.2012.11.005

Howell, J. M., \& Avolio, B. J. (1992). The ethics of charismatic leadership: Submission or liberation? Academy of Management Perspectives, 6(2), 43-54. doi:https://doi.org/10.5465/ame.1992.4274395

Jordan, P. J., Ashkanasy, N. M., \& Hartel, C. E. (2002). Emotional intelligence as a moderator of emotional and behavioral reactions to job insecurity. Academy of Management Review, 27(3), 361-372. doi:https://doi.org/10.5465/amr.2002 .7389905

Kant, L., Skogstad, A., Torsheim, T., \& Einarsen, S. (2013). Beware the angry leader: Trait anger and trait anxiety as predictors of petty tyranny. The Leadership Quarterly, 24(1), 106-124. doi:https://doi.org/10.1016/j.leaqua.2012.08.005

Kelley, R., \& Caplan, J. (1993). How bell labs creates star performers. Harvard Business Review, 7(4), 128-139. doi:https:// europepmc.org/article/med/10127037

Konovsky, M. A., \& Pugh, S. D. (1994). Citizenship behavior and social exchange. Academy of Management Journal, 37(3), 656-669. doi:https://doi.org/10.5465/256704

Krejcie, R. V., \& Morgan, D. W. (1970). Determining sample size for research activities. Educational and Psychological Measurement, 30(3), 607-610. doi:https://doi.org/10.1177/001316447003000308

Lee, J.-S., Joo, E.-J., \& Choi, K.-S. (2013). Perceived stress and self-esteem mediate the effects of work-related stress on depression. Stress and Health, 29(1), 75-81. doi:https://doi.org/10.1002/smi.2428

Luthans, F., Youssef, C. M., \& Avolio, B. J. (2007). Psychological capital: Developing the human competitive edge. Psychological Capital: Developing the Human Competitive, 5(7), 345-355. doi:https://doi.org/10.1093/acprof:oso/9780195187526 .001 .0001

Martins, A., Ramalho, N., \& Morin, E. (2010). A comprehensive meta-analysis of the relationship between emotional intelligence and health. Personality and Individual Differences, 49(6), 554-564. doi:https://doi.org/10.1016/j.paid.2010 .05 .029

Mills, A. (2014). Health care systems in low-and middle-income countries. New England Journal of Medicine, 370(6), 552-557. doi:https://doi.org/10.1056/nejmra1110897

Nadeem, M. T., Zia-uD din, M., Riaz, W., Shafique, M. Z., \& Sattar, A. (2018). The effects of employees empowerment on organizational performance: A case of hotel industry in Pakistan. International Journal of African and Asian Studies, 47(6), 89-94.

Naseer, S., Raja, U., Syed, F., Donia, M. B., \& Darr, W. (2016). Perils of being close to a bad leader in a bad environment: Exploring the combined effects of despotic leadership, leader member exchange, and perceived organizational politics on behaviors. The Leadership Quarterly, 27(1), 14-33. doi:https://doi.org/10.1016/j.leaqua.2015.09.005

Organ, D., \& Bateman, T. (1983). Job satisfaction and the good soldier: The relationship between affect and employee citizenship. Academy of Management Journal, 26(4), 587-595. doi:https://doi.org/10.5465/255908

Park, J. O., \& Seo, Y. S. (2010). Validation of the perceived stress scale (pss) on samples of Korean university students. Korean Journal of Psychology, 29(3), 611-629.

Pedrelli, P., Feldman, G. C., Vorono, S., Fava, M., \& Petersen, T. (2008). Dysfunctional attitudes and perceived stress predict depressive symptoms severity following antidepressant treatment in patients with chronic depression. Psychiatry Research, 161(3), 302-308. doi:https://doi.org/10.1016/j.psychres.2007.08.004

Pillai, R., Schriesheim, C. A., \& Williams, E. S. (1999). Fairness perceptions and trust as mediators for transformational and transactional leadership: A two-sample study. Journal of Management, 25(6), 897-933. doi:https://doi.org/10.1016/ S0149-2063(99)00031-8

Podsakoff, P. M., MacKenzie, S. B., Lee, J. Y., \& Podsakoff, N. P. (2003). Common method biases in behavioral research: A critical review of the literature and recommended remedies. Journal of Applied Psychology, 88(5), 879-903. doi: https://doi.org/10.1037/0021-9010.88.5.879

Richard, E., \& Emerson, R. (1976). Social exchange theory. Annual Review of Sociology, 2(1), 335-362.

Ruiz-Aranda, D., Extremera, N., \& Pineda-Galan, C. (2014). Emotional intelligence, life satisfaction and subjective happiness in female student health professionals: The mediating effect of perceived stress. Journal of Psychiatric and Mental Health Nursing, 21(2), 106-113. doi:https://doi.org/10.1111/jpm.12052 
Ryska, T. A. (2002). Leadership styles and occupational stress among college athletic directors: The moderating effect of program goals. The Journal of Psychology, 136(2), 195-213. doi:https://doi.org/10.1080/00223980209604150

Salovey, P., \& Mayer, J. D. (1990). Emotional intelligence. Imagination, Cognition and Personality, 9(3), 185-211. doi:https:// doi.org/10.2190/DUGG-P24E-52WK-6CDG

Schilling, J. (2009). From ineffectiveness to destruction: A qualitative study on the meaning of negative leadership. Leadership, 5(1), 102-128. doi:https://doi.org/10.1177/1742715008098312

Schutte, N. S., Malouff, J. M., Hall, L. E., Haggerty, D. J., Cooper, J. T., Golden, C. J., \& Dornheim, L. (1998). Development and validation of a measure of emotional intelligence. Personality and Individual Differences, 25(2), 167-177. doi:https:// www.sciencedirect.com/science/article/pii/S0191886998000014

Schutte, N. S., Malouff, J. M., Thorsteinsson, E. B., Bhullar, N., \& Rooke, S. E. (2007). A meta-analytic investigation of the relationship between emotional intelligence and health. Personality and Individual Differences, 42(6), 921-933. doi: https://doi.org/10.1016/j.paid.2006.09.003

Schyns, B., \& Hansbrough, T. (2010). When leadership goes wrong: Destructive leadership, mistakes, and ethical failures. New York, NY: IAP.

Schyns, B., \& Schilling, J. (2013). How bad are the effects of bad leaders? a meta-analysis of destructive leadership and its outcomes. The Leadership Quarterly, 24(1), 138-158. doi:https://doi.org/10.1016/j.leaqua.2012.09.001

Stajkovic, A. D., \& Luthans, F. (1998). Self-efficacy and work-related performance: A meta-analysis. Psychological Bulletin, 124(2), 240-250. doi:https://doi.org/10.1037/0033-2909.124.2.240

Taşdelen-Karçkay, A., \& Bakalım, O. (2017). The mediating effect of work--life balance on the relationship between work-family conflict and life satisfaction. Australian Journal of Career Development, 26(1), 3-13. doi:https://doi.org/ $10.1177 / 1038416216682954$

Tepper, B. J. (2000). Consequences of abusive supervision. Academy of Management Journal, 43(2), 178-190. doi:https:// doi.org/10.5465/1556375

Tepper, B. J., Duffy, M. K., Henle, C. A., \& Lambert, L. S. (2006). Procedural injustice, victim precipitation, and abusive supervision. Personnel Psychology, 59(1), 101-123. doi:https://doi.org/10.1111/j.1744-6570.2006.00725.x

Tepper, B. J., Duffy, M. K., Hoobler, J., \& Ensley, M. D. (2004). Moderators of the relationships between coworkers' organizational citizenship behavior and fellow employees' attitudes. Journal of Applied Psychology, 89(3), 455-460. doi:https://doi.org/DOI:10.1037/0021-9010.89.3.455

Thoroughgood, C. N., Sawyer, K. B., Padilla, A., \& Lunsford, L. (2018). Destructive leadership: A critique of leader-centric perspectives and toward a more holistic definition. Journal of Business Ethics, 151(3), 627-649. doi:https://doi.org/ 10.1007/s10551-016-3257-9

Tripathi, N., \& Bharadwaja, M. (2020). Empowering leadership and psychological health: The mediating role of psychological empowerment. Employee Responsibilities and RightsJournal, 32(6), 97-121. doi:https://doi.org/10.1007/s10672-020 $-09349-9$

Van Dusseldorp, L. R., van Meijel, B. K., \& Derksen, J. J. (2011). Emotional intelligence of mental health nurses. Journal of Clinical Nursing, 20(3-4), 555-562. doi:https://doi.org/10.1111/j.1365-2702.2009.03120.x

Wong, C. S., \& Law, K. S. (2002). The effects of leader and follower emotional intelligence on performance and attitude: An exploratory study. The Leadership Quarterly, 13(3), 243-274. doi:https://www.sciencedirect.com/science/article/ pii/S1048984302000991

Wu, T.-Y., \& Hu, C. (2009). Abusive supervision and employee emotional exhaustion: Dispositional antecedents and boundaries. Group \& Organization Management, 34(2), 143-169. doi:https://doi.org/10.1177/1059601108331217

Zhang, Y., \& Xie, Y.-H. (2017). Authoritarian leadership and extra-role behaviors: A role-perception perspective. Management and Organization Review, 13(1), 147-166. 